\title{
Implementation of Higher Education Publisher Management Model in Publishing Online-Based Scientific Work Towards World Class University: Study at Universities in Java and Bali
}

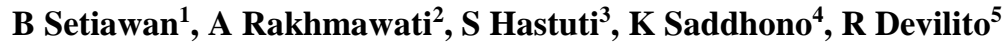 \\ $\left\{{ }^{1}\right.$ kaprodipbi@staff.uns.ac.id \} \\ 1,2,3,4,5 Universitas Sebelas Maret Surakarta, Indonesia
}

\begin{abstract}
The purpose of this study is the implementation of the development of a management model for tertiary publishers in publishing scientific work towards World Class University in Central and Bali Islands. While the specific purpose of this research is an implementative study of the management model of higher education publishers in Java and Bali in publishing quality scientific work. The method to be used in this study is descriptive qualitative by conducting focus group discussions, seminars, workshops, and training. The results of this study were able to encourage university publishers to become productive, independent, professional, and able to publicize institutions' intellectual assets, to produce quality and useful products for the community, and to be useful in the development of science, technology and art.
\end{abstract}

Keywords: Publisher, Management, University Press, Java, Bali

\section{INTRODUCTION}

The problems faced by university press are generally change of leader, management weaknesses, funding and tool restrictions, manuscript problems, as well as internal problems related to institution neglect of the importance of college publisher institution existence. Another problem resulted in university press inability to compete private publisher is its sensitivity of market desires [1]. However, the more global and complex problem is specifically from writing habit itself. This has been discussed Congress I of Indonesia Higher Education Publisher Association (APPTI) in Universitas Sebelas Maret, Surakarta (September, 2011) which is continued in Universitas Brawijaya, Malang (2012) and Politeknik Media Kreatif, Jakarta (2013).

Human quality resource in university press is one of important problems which get University Press less developed. It is reflected by work principle, quality and product appearances. For example, cover book design and layout published by university press generally looks clumsy and uninteresting. Consequently, people don't want to buy it because of uninteresting appearance, even the content is good [2]. University press conditions in Java and Bali also show the same. There were some problems required to pay attention in terms of management and development. Hence, the study related to university press management and development model in Java and Bali needs to conduct for achieving productive university press 
and supporting tri dharma of higher education comprehensively, especially in publishing higher education intellectual assets [3].

Publication is one of important sectors compulsorily conducted by academicians. The academicians give contribution for publication sector in terms of scientific book, textbook, monograph, journal, etc. Consequently, they have an opportunity to share their thought and idea to society in higher education environment or beyond [4]. Higher education has an important role in giving opportunities and wide spaces for academicians to publish their scientific works in academicians' affiliation publisher. In accordance to university press, higher education is considered as gatekeepers of ideas or primary gate keeper of scientific publication which gives contribution in not only producing books but also taking responsible of creating scientific community [5]. It indicates that book is an effective medium to increase intelligence which is effectively done in the place supporting intelligence development. Therefore, book is the input and output of collective intelligence, and the role of university press is to produce a quality and beneficial book.

University press is originally created with spirit and intention to support tri dharma of higher education implementation [6]. To realize that purpose, university press begins publishing reading textbook. By publishing this kind of book, university press is expectedly able to reinforce tri dharma of higher education implementation, related to education and teaching. Besides, the writers are expectedly the lecturers who teach in higher education, where the publisher is organized. The second is research result conducted by lecturer and student. Consequently, it can be socialized to society. This publication also supports the success of the second dharma of higher education in terms of research. The third is popular scientific books about practical skill. While the first and second books are distributed in society located in and beyond higher education environment, the third book is more than that. This book is usually used by students while Kuliah Kerja Nyata $(\mathrm{KKN})$ or Learning through Real Work in dedication for village and it is compatible with the third dharma related to dedication.

Globalization has contributed changes in terms of accessing science. Due to sophisticated communication and information technology, society can access science from various disciplines. Consequently, it decreases society dependency over conventional books. However, this condition doesn't become a huge problem for university press as long as society based science can be constructed, with reference to (1) critical, being able to differentiate good and bad books, readable and unreadable books, (2) skeptical, willing to believe in information distributed, (3) open, willing to be open-minded to all values come, and (4) universal, always using universal parameter in working.

University press must contribute in constructing society based science. It has to be done by publishing text book, reading textbook, reference books, and report of research books. Those books can give information about science to society. Moreover, those can stimulate society to adapt reality about science progress. However, the published books are available only in a small amount, presented uninterestingly and distributed in a small range, so books from university press cannot compete books from private publisher. Consequently, university press has to sell book directly. Besides, university press can make collaboration with mass media to promote books. While society need mass media, information distributed by mass media always become interesting. Therefore, information about scientific books in mass media will stimulate society to find it out and to buy it. 


\section{RESEARCH METHOD}

The approach of this study was descriptive qualitative. It aims to describe university press development model in higher education in Central Java. Besides, the study also employed Focus Group Discussion (FGD), seminar, workshop and training. Research subjects included: (1) institution related to university press, Pusgrafin as University press coach in Indonesia, Indonesia University Press Association (AUPI) and Indonesia Higher Education Publisher Association (APPTI), (2) university press in Central Java higher education with reference to Graphic and Media Directory 2007-2008, including UNS Press (Surakarta), UNNES Press (Semarang), UMS Press (Surakarta), ISI Press (Solo), UNDIP Press (Semarang), Unsoed Press (Purwokerto), Gama Press (Yogyakarta) and UNY Press (Yogyakarta); and (3) personnel involved in university press including higher education chairperson, lecturer, university press chairperson and staff, as well as students.

Source of data included informants, events and documents. (1) Informants were university press supervisor, university chairperson, lecturer, university press chairperson and staffs as well as student. (2) Events were the events related to university press management in central java in terms of publication process preparation, prepublication, publication process and post publication process. (3) Documents referred to written information including (a) university press products, (b) management activity tools and university press work mechanism, and (3) interview result transcriptions.

\section{RESULT AND DISCUSSION}

\subsection{University Press Management}

The study about university press has been conducted by Saddhono (2010) from Research and Development Institute (Balitbalng) of UNS Press entitled "Pengembangan UNS Press Menjadi Unit yang Mandiri dan Produktif (UNS Press Development to be independent and productive unit/institution)." It related to UNS Press management about internally selfdevelopment. It discussed about UNS Press reposition with new paradigm of management to be more independent, professional and productive. With reference to professional management, UNS is expected to be one of units in Universitas Sebelas Maret which can give profit. Therefore, the present study is only related to UNS Press internal management, including administration, pra publication, publication and pasca publication units.

Besides, the present study is also relevant to another previous study entitiled "Kesalahan Pemakaian Bahasa pada Buku Karya Dosen Universitas Sebelas Maret (Kajian Buku Program Buku Teks 2004-2009)" The Errors of Language Use in Books written by Lecturer of Universitas Sebelas Maret (A Program Book Study of 2004-2009 Textbooks) (2009). The study analyzed books published in UNS Press collaborating with Institute of Education and Development in UNS. It investigated certain language use related to editorial management and the present research. The result showed that there were errors and non-standardized language used. Consequently, the firmer editing is required, in relation to content, language and presentation editing. It supported the present research of university press management, especially editorial management. If language use errors can be solved, the books will get a positive impact. Besides, books will be more attracting in terms of language use and it directly or indirectly will improve book quality [6].

The study related to university press management was entitled "Peran Penyunting Buku Menuju Manajemen Redaksional Modern (The Role of Book Editor in Achieving Modern Editorial Management)" [7]. It investigated editor role of publication management in university 
press. It indicated that the good and bad quality of books depends on an editor. His/her jobs are related to not only book content but also the more complex things. It is illustrated as the present study conducted. Editor begins working at the time when the manuscript is submitted to university press. It implies that editor works from manuscript assessment phase. In this phase, editor makes coordination with prepublication, publication process, post publication units. Henceforth, an editor plays an important role in book publication.

Moreover, chairperson or director or the number one who manages the publisher also plays an important role. Abrar (2006) argues that there are many challenges to be a chairperson of university press. It is related to how s/he handle writers, his/her reaction in facing science and technology development, etc. Furthermore, the required characteristics as university press chairperson is willing to find out the qualified manuscript to publish. Although lecturer in homebased university has less interest in publication, chairperson has to be optimistic. It can be done by looking it out in another higher education. However, it will be peculiar if chairperson himself never publishes any books. Chairperson's skill in writing book will be a magnet for another writers. If chairperson never writes any books, s/he doesn't experience how hard a writer finish a manuscript with all struggle in it.

\subsection{University Press Profile}

A good university press has goals required to fulfill within a certain time. They are vision and mission. As an organization, university press must have vision and mission for university press development. Both vision and mission cannot be separated. Vision is the ability to see the foresight related to target to be achieved within in certain time. Therefore, vision restrictedly deals with insight without action. Besides, mission refers to planning phase of events (actions) which will be conducted to realize vision [8].

Every university press must have vision and mission as a guideline and policy determination in academic publications like university press in Java and Bali. Each university press has vision and mission indicating the future goals. University press in Bali takes mission priority to increase capacity and capability, to optimize science and technology utilization for supporting quality service, strengthening academic habit, scientific work, social networking in national, regional and international areas. Besides, Udayana press specifically maximizes mission in internal aspect to create academic atmosphere through increasing motivation, passion of reading and writing books among civitas academicians of Universitas Udayana. In external aspect, publishing books aims to create intellectual image and reputation of Universitas Udayana that gives spirit of enlighten as a concrete and continued dedication for society. In international aspect, it supports Universitas Udayana effort to be a World Class University like Universitas Sebelas Maret through publishing quality, innovative and international books.

\subsection{Feature program}

Among university press in Central Java and Special Region of Yogyakarta (DIY), Gajah Mada University Press (GMUP) is the most successful publisher. Since created in 1971, GMUP has published about 1500 books and mostly been used in higher education level, not only in Universitas Gajah Mada but also in international higher education. This cannot be separated from feature program of university press management.

Muhammadiyah University Press (MUP) also begins to consider recent publication market development for realizing its feature program by developing its role as a publisher, even MUP has no own printing machine. This effort begins in recruiting professional layout workers. MUP role is expanded by distributing publication in book stores, as a market target of MUP products. 
Consequently, society can reach MUP products widely, and MUP and Universitas Muhammadiyah Surakarta (UMS) are known. Besides, MUP also utilizes service provider sector in terms of websites in seminar or call for paper organized through online system. This step is done to help UMS in organizing scientific activity with a good standard.

The next example of university press management is Universitas Sebelas Maret, Surakarta. The steps for writing higher education books developed in UNS is the inspirative ones. The first phase is to determine book as reference. Reference can be seen as an ideal example or book model. The existence of book will encourage others to write, in terms of book content or others [9]. There are many knowledge containing in reference book, not only from book content itself but also from language use which can be utilized as an example for writing higher education book. The second phase is to exploit interesting and communicative language use. Language as a medium to determine book quality. Language use in book must be readable and natural. Consequently, writer is required to have good reading comprehension. Besides, writing must be done totally and intend to contribute various fields of science. Moreover, skill of mastering the content must be good because the analysis will be deeper and focus. Furthermore, there is a need to add some interesting part like inspirative illustration or stories. This can stimulate both reader' right and left brain to work equally, and reader will comprehend all contain of book holistically, in terms of written and visual language [10]. Consequently, writing book which can function all area of brain is required, because book is not only for entertaining but also for making reader clever. University press in Bali has the strengths to publish national and international levels of books through maximizing art field and local wisdom which simultaneously contributes scientific and education aspects which are compatible with higher education need.

\section{CONCLUSSIONS}

University press is the most important pillar in implementing Tri Dharma of higher education and has a vital role in publishing and distributing higher education intellectual asset to wide society. The good management will make university press professional. The very aspects requiredly to pay attention are related to (1) manuscript, including manuscript requirement, manuscript source, manuscript determination, manuscript administration, copyright and publication agreement, as well as ISBN/ISSN; (2) production unit management, including manuscript production process (pra publication, publication process, pasca publication) and production cost; (3) marketing and distribution unit management; including market and marketing, stocking, marketing link and distribution; and (4) administration and funding unit management. Universitas Sebelas Maret has proved well-managed publication will give a possitive impact to higher education. Besides, the academic atmosphere will always spread in all publication activities. However, every policy has both positive and negative aspects, so the program must be investigated for the future improvement.

\section{REFERENCES}

[1] N. Darmanto, "University Press sebagai Corong Masyarakat Ilmiah," Pusgrafin, Jakarta, 2006.

[2] I. Kleden, "Buku, Kecerdasan, dan Pendidikan," in Menggagas Pendidikan Rakyat: Otosentrisitas Pendidikan dalam Wacana Politik Pembangunan, D. S. Anshori, Ed. Bandung: Alqaprint, 2000.

[3] A. Nadhya, "Siapa Sebenarnya Direktor University Press," in Penerbitan MalaysiaIndonesia. Mengukuhkan Jaringan Penebitan Serantau, H. M. Adnan, Ed. Kuala 
Lumpur: Penerbit Universiti Malaya, 2006.

[4] Arifzan, "Struktur Organisasi dan Rincian Tugas University Press," in Seminar dan Workshop Penerbit University Press, 2006.

[5] M. M. Ishak, "Universiti dan Penerbitan Ilmiah di Malaysia," in Penerbitan MalaysiaIndonesia: Mengkuhkan Jaringan Penerbitan Serantau, H. M. Adnan, Ed. Kuala Lumpur: Penerbit Universiti Malaya, 2006.

[6] A. Core, "Publisher as Gatekeepers of Idea," in Perspective on Publishing, P. G. Altbach, Ed. Lexington: Lexington Books, 1976.

[7] K. Saddhono, "Peran Penting University Press sebagai Pilar Utama Tridharma Perguruan Tinggi," Jurnal Akademika, vol. 1, no. 1, 2009.

[8] K. Saddhono and P. Sumedi, "Prospek Perkembangan Industri Grafika di Indonesia dan Pengaruhnya terhadap Perkembangan Perbukuan Perguruan Tinggi," in Seminar dan Workshop Nasional Penulisan dan Penerbitan Buku Ajar, 2008.

[9] M. T. Djamara, Direktori Grafika dan Media 2007-2008. Jakarta: Pusat Grafika Indonesia (Pusgrafin) Departemen Pendidikan Nasional, 2007.

[10] A. R. Siregar, "Membangun Pusat Data Penerbit Universiti antara Rumpun Melayu untuk Menunjang Pemasaran Bersama," in Malaysia-Indonesia: Mengkuhkan Jaringan Penerbitan Serantau, H. M. Adnan, Ed. Kuala Lumpur: Penerbit Universiti Malaya, 2006. 